R.V. Vlasenko, Master,

O.V. Bialobrzeski, PhD

Kremenchuk Mykhailo Ostrohradskyi National University, 20 Pershotravneva Str., 39600 Kremenchuk, Ukraine;

e-mail: laplandec267@gmail.com

\title{
STUDY OF THREE-PHASE ACTIVE POWER FILTER OPERATION USING NON-SINUSOIDAL VOLTAGE
}

\begin{abstract}
Р.В. Власенко, О.В. Бялобржеський. Дослідження роботи трифазного силового активного фільтра при несинусоїдальній напрузі живлення. Силовий активний фільтр призначений для компенсації неактивних складових потужності. Мета: Метою дослідження $\epsilon$ оцінка якості роботи трифазного силового активного фільтра при спотворенні напруги в електричній мережі живлення, викликаному впливом нелінійних навантажень, з подальшим порівнянням двох алгоритмів активної фільтрації - теорії потужності Фрізе і $p$ - $q$ теорії миттєвої потужності. Матеріали і методи: Розглянуто трифазний силовий активний фільтр, підключений паралельно до електричної мережі через індуктивність. Для дослідження режимів роботи фільтра при нелінійному навантаженні з несинусоїдальною напругою живлення у програмному середовищі Matlab/Simulink реалізовано модель електроенергетичної системи. В якості алгоритму визначення неактивних складових потужності розглянуто теорію Фрізе і $p$ - $q$ теорію. Результати: Отримано часові діаграми струму мережі після компенсації при застосуванні теорії Фрізе і $p-q$ теорії. Побудовано графіки ефективності компенсації реактивної потужності, падіння коефіцієнта спотворення струму мережі і похибки активної потужності при зміні кута керування тиристорним перетворювачем.

Ключові слова: силовий активний фільтр, теорія Фрізе, $p-q$ теорія.

R.V. Vlasenko, O.V. Bialobrzeski. Study of three-phase active power filter operation using non-sinusoidal voltage. The active power filter designed to compensate inactive power components. Aim: The aim of the study is to assess the quality of the three-phase active power filter in the distortion of the mains voltage supply, which is caused by the influence of non-linear loads, and then comparing the two active filtering algorithms - the Fryze power theory and $p-q$ theory of instant power. Materials and Methods: Reviewed a three-phase active power filter connected in parallel to the mains via inductance. To study the modes of filter with non-linear loads with non-sinusoidal voltage programmed in Matlab/Simulink the model of electricity system is implemented. As the algorithm of implementation for determining of inactive components of power the Fryze theory and $p$ - $q$ theory were considered. Results: Obtained a time diagrams of network current after compensation when applying the theory of Fryze and $p-q$ theory. Built the graphs of efficiency of reactive power compensation, fall of coefficient of network current distortion and errors of active power under the changing of firing angle of thyristor converter.

Keywords: active power filter, Fryze power theory, $p-q$ theory.
\end{abstract}

Introduction. Today semiconductor devices are used widely in industrial electrical networks for different purposes. They are used in thyristor rectifiers, in uninterruptible power supplies, computers, electronic devices and others. The use of power electronics devices makes it possible to develop new cost-effective and reliable solutions in the management and control of electricity at power plants.

However, considering features of the majority of power electronics schemes, semiconductor devices are inherent the nonlinear dynamic characteristics that lead to a distortion of current and voltage at the point of universal adherence of industrial loads. Therefore, we can say that semiconductor devices have become the major polluters for modern power systems [1]. Thus, the study of the Canadian Electrical Association show that the problems with the quality of electricity supply in Canada, including failures of voltage, transient processes, higher harmonics at approximate estimates lead to losses in production of 1.2 billion US dollars per year [2]. Nowadays the company is investing more in high-tech and innovative devices to improve power quality [2]. The condenser batteries which are mainly used in industrial plants for reactive power compensation calculated for constant loading. With each drop of loading the capacitor banks require recalculation of reactive power balance, in addition condenser installations are very sensitive to higher harmonics. To overcome this situation Davydov O. [3] proposes to apply the active power filter (APF). Search of system solutions to reduce the impact of higher harmonics usually begins with some research on industrial sites.

The aim of the study is to assess the quality of the three-phase active power filter when distortion of the mains voltage supply, which is caused by the influence of non-linear loads, and then comparing 
the two active filtering algorithms - the Fryze power theory and $p-q$ theory of instant power.

Materials and Methods. Consider three-phase APF, connected in parallel to the electricity network via inductance. This filter is designed to reduce the higher harmonic of current and reactive power compensation caused by nonlinear loads.

Structurally APF consists of the following elements (Fig. 1):

- Power supply;

- Current generation block;

- Pulse shaping block;

— Voltage and current sensors.

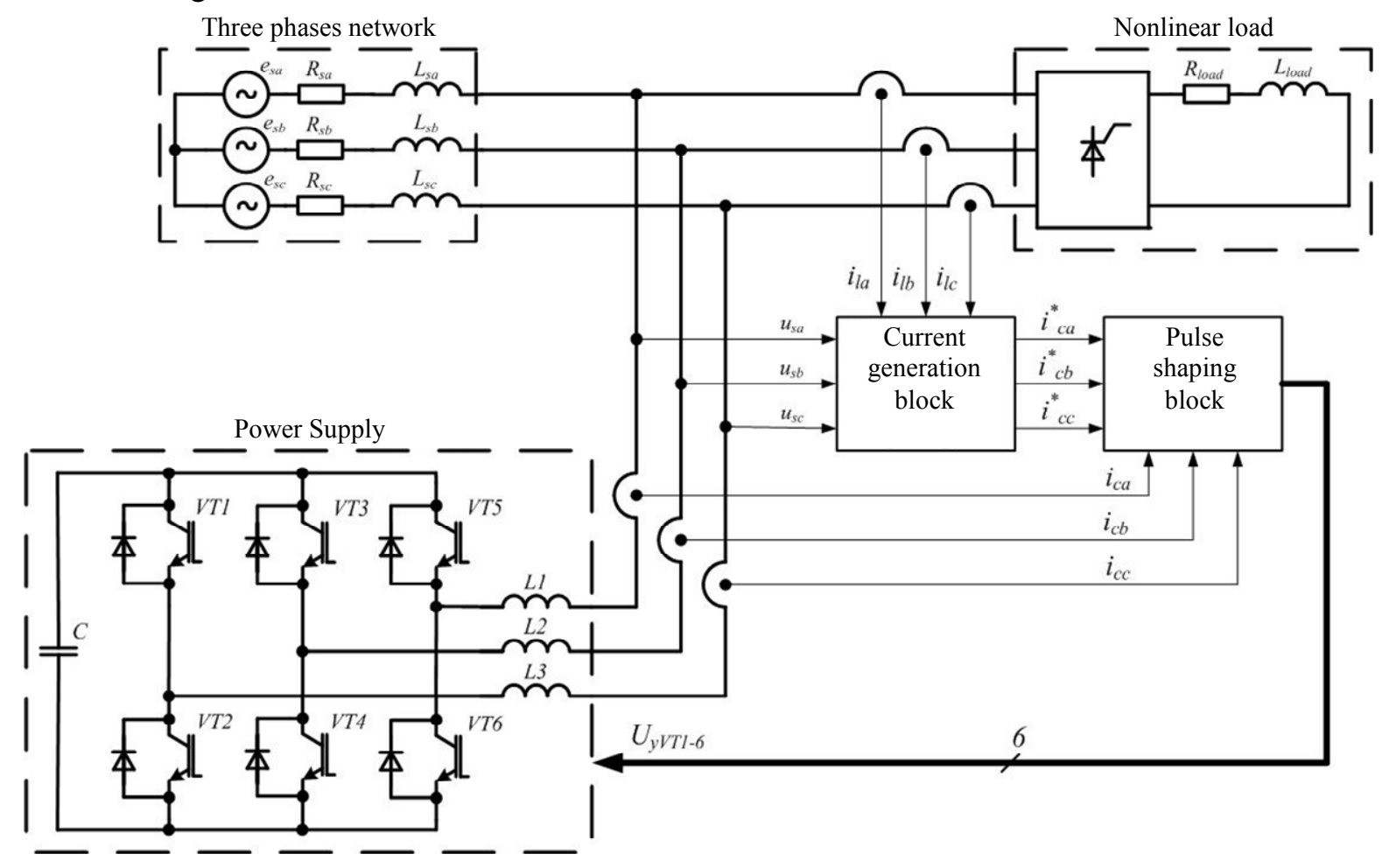

Fig. 1. Functional diagram of a three-phase APF

The power supply includes three-phase transistor transformer, three-phase inductor $L 1 \ldots L 3$ and storage capacitor $C$. Three-phase transistor converter includes an IGBT transistors VT1 ...VT6. Group of inductances $L 1 \ldots L 3$ provides the formation of a given current, increasing the voltage on the capacitor. Through the inductances the process of charge and discharge the capacitor $C$ is formed together.

Separately consider an operation of definition blocks of given network current and forming the control APF pulses.

In Current generation block the current calculated from the measured voltage and a current of loading. There are several power theories exist today to determine the APF current for active filtering, which will be discussed below [4].

Further management of transistor converter is due to control impulses which generated by Pulse shaping block of APF under the current set.

APF management can be divided into three stages. In the first stage, voltage signals and a current of loading are fixed by using the current transformers or sensors based on the Hall effect. In the second stage, in the block of definition of APF given current the currents for compensation of inactive components of power generated. In the third stage, the pulses for transistors key management are generated, which are created by means of pulse modulation methods. APF management is carried out 
by discrete, analog and digital devices or additional microelectronic devices such as separate microcomputer DSP chip (digital signal processor) [5].

Capacitor $C$ in the DC link is used as the source of voltage, and inductance for limitation of the rate of rise of current. The principle of filtering is that APF leads in the current into the network by generating output voltage of the converter. This current flow is achieved when switching transistors. Voltage of the condenser must be maintained in a certain specified range of values achieved by power flowing through the converter.

For the APF correct work we must accurately and quickly determine the specified APF current [6] that to be added to the load current for reactive power compensation and reduction of higher harmonics. The actual filtering effect depends on the performance of APF and the properties of the loading, which is subject to compensation.

To realize the control algorithm in the block of definition of APF given current authors applied the Fryze power theory and $p-q$ theory of instant power. The chosen theories of power are widely used in the studies of APF operation [6].

The key management method of impulse control - adaptive current control relay with defined upper and lower limits of the zone hysteresis - which proposed in [7], is implemented in Pulse shaping block. The advantage of this method is that it is universalize for different types of load, and thanks to adaptive regulation reduces the content of higher harmonic of current in the power supply.

To study the modes of operation of three-phase APF programmed in Matlab / Simulink the model of electricity system (Fig. 2) [7] realized, which includes the following structural elements: electricity network (Three-Phase Source) with equivalent inductive and active resistance; "non-linear load" connected to the mains through the reactor (Reactor 2) which is represented by thyristor converter (Thyristor Converter) with active-inductive load (RL-load); three-phase transistor converter (Transistor converter); Current generation block and Pulse shaping block.

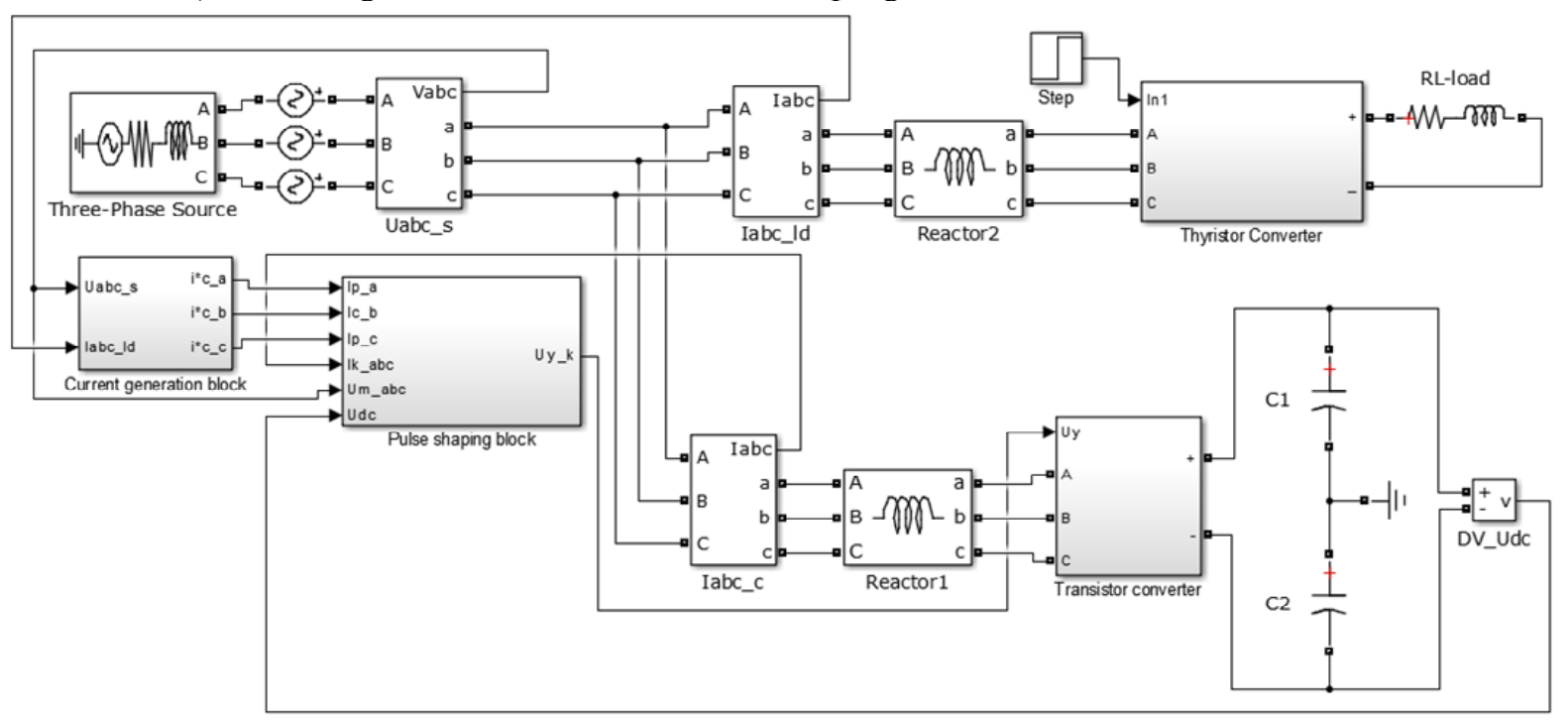

Fig. 2. The model of the three-phase APF power system

Parameters of structural elements of the scheme following. Nonlinear load represented by the induction furnace has active power at the main harmonic $P=30 \mathrm{~kW}$ and reactive power $Q=66 \mathrm{kVAr}$; thyristor (Thyristor converter) with active-inductive load ( $R L$-load) $R_{l d}=2 \mathrm{Ohm}$ and $L_{l d}=0.0116 \mathrm{H}$ corresponds to calculation of induction furnace (active) power. Electricity is provided from the power grid (Three-Phase source) with a rated voltage of $U_{s}=380 \mathrm{~V}$ and frequency $50 \mathrm{~Hz}$. Equivalent active and reactive resistances of power grid are calculated based on $7 \%$ allowable voltage losses on them and are respectively $R_{s}=0.1 \mathrm{Ohm}$ and $L_{s}=1 \cdot 3 \cdot 10^{-5} \mathrm{H}$. Electrical parameters of the APF determined by the method proposed Zakis and Rankis [8]: frequency of transistors switching $-f_{c}=15 \mathrm{kHz}$, the 
inductance of the APF reactor $-L_{r}=0.0054 \mathrm{H}$, capacitance $-C 1=C 2=40 \mathrm{mlF}$, the voltage drop on the capacitors $-U_{d c 1}=U_{d c 2}=1 \mathrm{kV}$.

The APF given current - $i_{c_{-} a}^{*}, i_{c_{-} b}^{*}, i_{c_{-} c}^{*}$ (Fig. 2) is formed in Current generation block.

The research phase of APF operating modes in the nonlinear load with non-sinusoidal voltage network was carrying out. As a source of voltage in each phase was introduced the third harmonic of voltage with amplitude $U_{3}=38 \mathrm{~V}$.

During the study we have received current network diagram $i_{S}$ after compensation at changing time $t$ firing angle of thyristor converter in the range of $15 \ldots 45^{\circ}(t=0,1 \mathrm{sec})$ applying the Fryze theory (Fig. 3, $a$ ) and $p-q$ theory (Fig. 3, $b$ ).
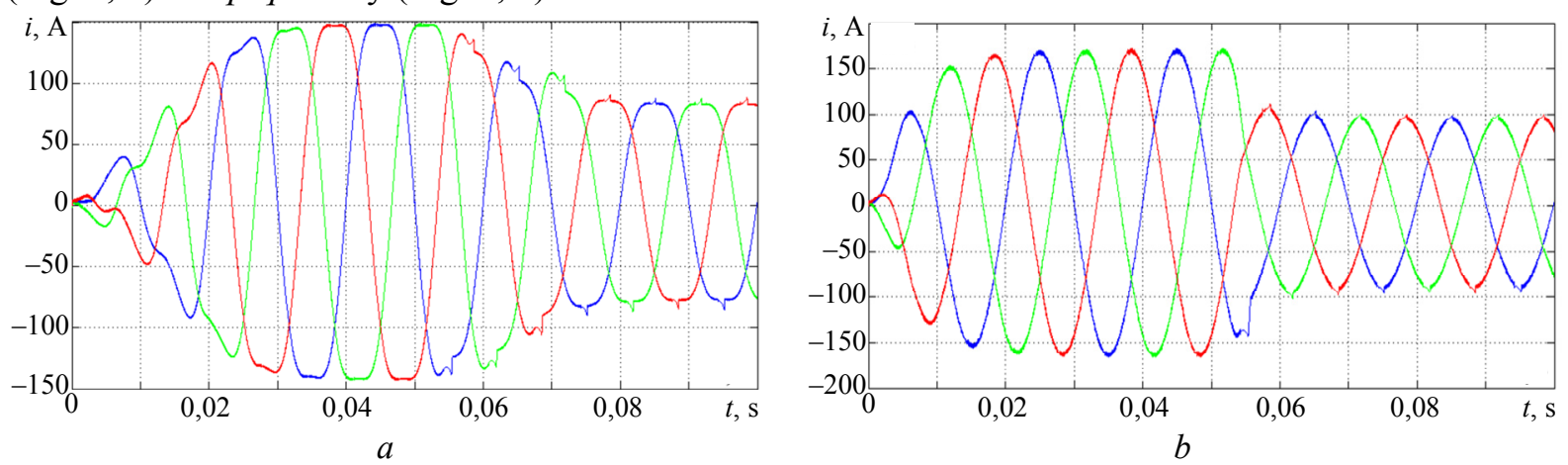

Fig. 3. Oscillograms of network current after compensation: Fryze theory (a); p-q theory (b)

As shown in the obtained diagrams when APF is working on Fryze theory the network current has non-sinusoidal shape (Fig. 3,a), while at work using $p$ - $q$ theory network current has sinusoidal shape (Fig. 3, $b$ ).

For quantitative assessment of APF the parameters chosen:

- effectiveness of reactive power compensation:

$$
\varepsilon_{Q}=\frac{Q_{l d}-Q_{s}}{Q_{l d}} \cdot 100 \%,
$$

where $Q_{s}$ - reactive power of network,

$Q_{l d}$ - reactive power of load;

— reduce rates of distortion of network current

$$
\varepsilon_{\text {THDi } i}=\frac{T H D_{I_{-} l d}-T H D_{I_{-} s}}{T H D_{I_{-} l d}} \cdot 100 \%,
$$

where $T H D_{I_{-} S}$ - distortion coefficient of network current,

$T H D_{I_{-} l d}$ - distortion coefficient of load current;

- relative error for active power:

$$
\Delta P=\frac{P_{l d}-P_{s}}{P_{l d}} \cdot 100 \%,
$$

where $P_{s}$ - active power of network;

$P_{l d}$ - active power of load.

Results. As the result of experiments, the dependency graphs of these parameters from firing angle of thyristor converter were obtained:

- effectiveness of reactive power compensation $\varepsilon_{Q}$ (Fig. 4);

- coefficient of decrease of distortion current network $\varepsilon_{T H D}$ (Fig. 5);

- relative error for active power $\Delta P$ (Fig. 6).

Each dependency individually designed in the application of Fryze theory and $p-q$ theory. 


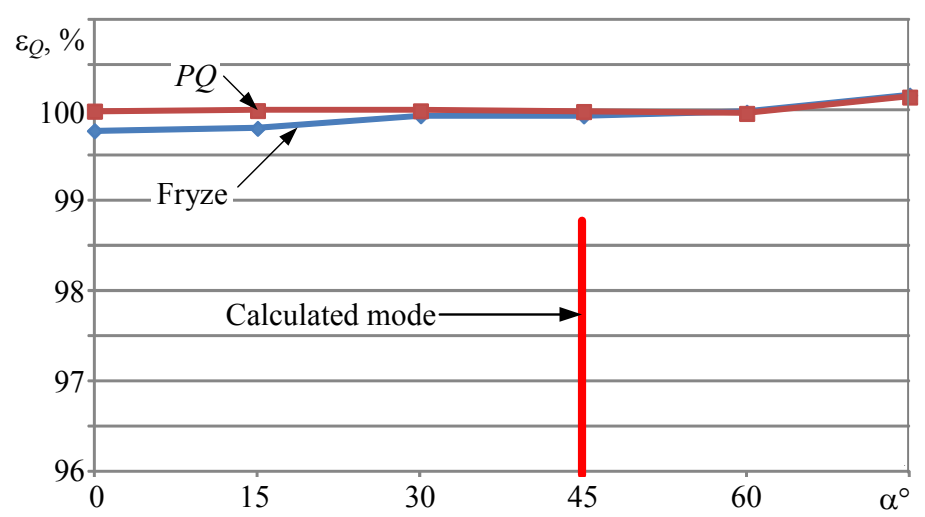

Fig. 4. Dependence of efficiency of reactive power compensation on firing angle of thyristor converter $\alpha=0 . .75^{\circ}$

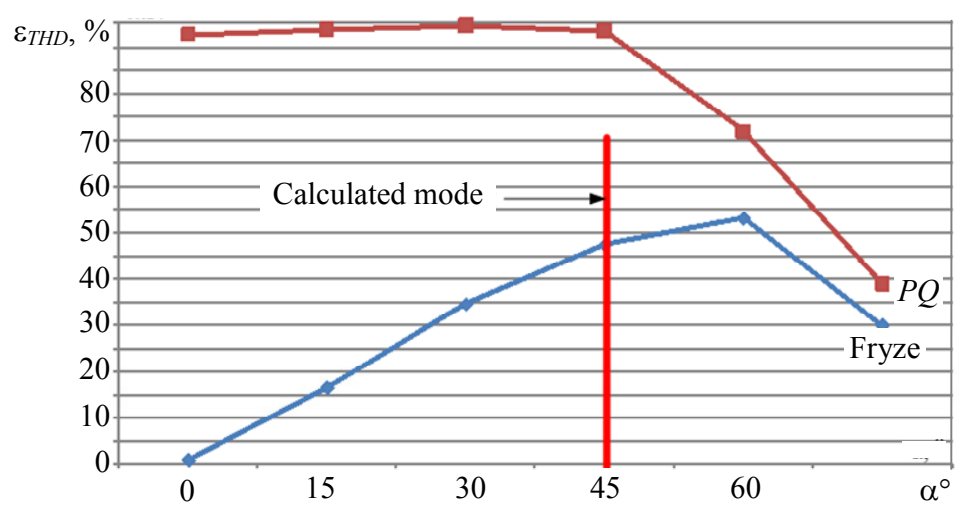

Fig. 5. Dependence of coefficient of decrease of distortion current network on firing angle of thyristor converter $\alpha=0 \ldots 75^{\circ}$

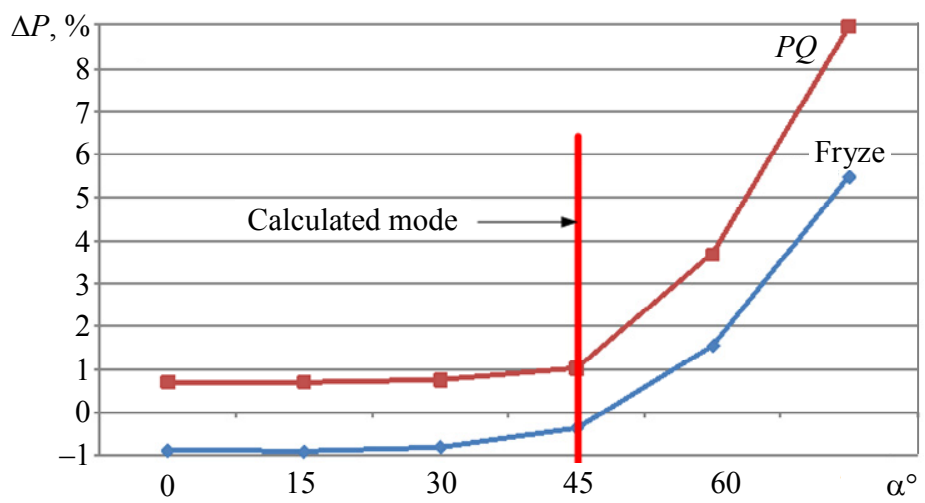

Fig. 6. Dependence of relative error for active power on firing angle of thyristor converter $\alpha=0 \ldots .75^{\circ}$

From the analysis of Fig. 4...6 we conclude the following. At the firing angles of thyristor converter $0<\alpha \leq 45^{\circ}$, which correspond to the current APF regime, efficiency of reactive power compensation exceeds $99 \%$ as at Fryze theory as using $p-q$ theory. In this case, the decrease of coefficient of network current distortion exceeds $90 \%$ for $p-q$ theory, whereas for the Fryze theory it is less than $48 \%$. The relative error for active power at firing angle of thyristor converter $0<\alpha \leq 45^{\circ}$ for the Fryze theory is zero, and for $p-q$ theory is less than $1 \%$.

Indexes are generalized and put into the table. 
Numerical results

\begin{tabular}{c|c|c|c|c|c|c}
\hline \multirow{2}{*}{ Variant } & \multicolumn{3}{|c|}{$\alpha \leq 45^{\circ}$} & \multicolumn{3}{c}{$\alpha>45^{\circ}$} \\
\cline { 2 - 7 } & $\varepsilon_{O}, \%$ & $\varepsilon_{T H D i} \%$ & $\Delta P, \%$ & $\varepsilon_{O}, \%$ & $\varepsilon_{\text {THDi }}, \%$ & $\Delta P, \%$ \\
\hline Fryze & 99 & $<48$ & 0 & $99.9 \ldots 100$ & $54 \ldots 30$ & $1.5 \ldots 5.5$ \\
\hline$P Q$ & 99 & $>90$ & $<1$ & $99.9 \ldots 100$ & $72 \ldots 39$ & $4 \ldots 9$ \\
\hline
\end{tabular}

Conclusions. By increasing the level of harmonics and reactive power higher than estimated value, the figures of quantitative assessment of APF at the application of the algorithm for determining a given APF current based on the Fryze theory and $p$ - $q$ theory reduce.

This leads to overcompensation of reactive power, increasing of coefficient of current network harmonic and increasing of errors quantity for the active power.

Applying the algorithm of definition given APF current based on the theory of power Fryze with non-sinusoidal network voltage reduces the efficiency of the filter-compensating device because this theory ignores the power voltage distortion and decreasing of coefficient of the distortion of network current and, consequently, $\varepsilon_{T H D i}<54 \%$.

In applying $p-q$ theory of instantaneous power as an algorithm for determining the given APF current at firing angle of thyristor converter $\alpha \leq 45^{\circ}$ decline coefficient of distortion of network current is on average $93 \%$, which is quite high. I.e., $p-q$ theory takes into account the possible presence of non-sinusoidal voltage.

\section{Лiтература}

1. Baliga, B.J. Fundamentals of power semiconductor devices / B.J. Baliga. — Berlin: Springer, 2008. $1069 \mathrm{p}$.

2. Rudnick, H. Delivering clean and pure power / H. Rudnick, J. Dixon, L. Moran // IEEE Power \& Energy Magazine. - 2003. - Vol. 1, Issue 5. - PP. 32 - 40.

3. Давидов, О.Ю. Аналіз засобів компенсації реактивної потужності / О.Ю. Давидов, О.В. Бялобржеський // Вісник КНУ імені Михайла Остроградського. — 2010. — Вип. 3, Ч. 1. C. $132-136$.

4. Brandstetter, P. Control Algorithms of Active Power Filters / P. Brandstetter, P. Chlebis, P. Simonik // Proceedings of PIERS 2010 in Cambridge, July 5-8, 2010. — Cambridge: The Electromagnetics Academy, 2010. - PP. 429 - 433.

5. Singh, B. Active power line conditioners for power quality improvement - A prospective / B. Singh // Journal of the Indian Institute of Science. — 1997. - Vol. 77, No. 6. — PP. 565 - 583.

6. Современные теории мощности и их использование в преобразовательных системах силовой электроники / И.Ф. Домнин, Г.Г. Жемеров, Д.С. Крылов, Е.И. Сокол // Технічна електродинаміка. Тем. випуск «Проблеми сучасної електротехніки». — 2004. - Ч. 1. - С. 80 - 91.

7. Власенко, Р.В. Порівняння методів компенсації неактивної потужності трифазним силовим активним фільтром з адаптивним релейним регулятором струму / Р.В. Власенко, О.В. Бялобржеський / Електротехніка та електроенергетика. — 2014. — №2. - С. 20 - 27.

8. Zakis, J. Comparison of flexible systems of reactive power compensation / J. Zakis, I. Rankis // Proceedings of $5^{\text {th }}$ International Symposium "Topical Problems in the Field of Electrical and Power Engineering", Kuressaare, Estonia, January 14-19, 2008. - Kuressaare: Tallinn University of Technology, 2008. - PP. $99-102$.

\section{References}

1. Baliga, B.J. (2008). Fundamentals of Power Semiconductor Devices. Berlin: Springer.

2. Rudnick, H., Dixon, J., \& Moran, L. (2003). Delivering clean and pure power. IEEE Power \& Energy Magazine, 1(5), 32 - 40. DOI:10.1109/MPAE.2003.1231689 
3. Davydov, A.Y., \& Bialobrzeski, A.V. (2010). Analysis of facilities of indemnification of reactivepower in electrical engineering systems. Transactions of Kremenchuk Mykhailo Ostrohradskyi National University, 3(1), $132-136$.

4. Brandstetter, P., Chlebis, P., \& Simonik, P. (2010). Control algorithms of active power filters. In Proceedings of Progress in Electromagnetics Research Symposium (PIERS'2010) (pp. 429 — 433). Cambridge: The Electromagnetics Academy.

5. Singh, B. (1997). Active power line conditioners for power quality improvement - A prospective. Journal of the Indian Institute of Science, 77(6), 565 - 583.

6. Domnin, I.F., Zhemerov, G.G., Krylov, D.S., \& Sokol, E.I. (2004). Modern power theories and their use in power electronics converter systems [Special issue]. Tekhnichna Elektrodynamika, 1, 80 - 91.

7. Vlasenko, R.V., \& Bialobrzeski, O.V. (2014). Adaptive control of current controller relay for threephase active power filter. Electronics and Electricity, 2, $20-27$.

8. Zakis, J., \& Rankis, I. (2008). Comparison of flexible systems of reactive power compensation. In R. Lahtmets (Ed.), Proceedings of $5^{\text {th }}$ International Symposium "Topical Problems in the Field of Electrical and Power Engineering” (pp. 99-102). Kuressaare: Tallinn University of Technology.

Received December 2, 2015 Accepted March 29, 2016 